\title{
ORGANIZATION OF EVENTS «CHALLENGE». ELECTRONIC ENVIRONMENT OF EVENTS
}

\author{
Assistant Professor Alona Nieliepova \\ Ukraine, Kyiv, National University of life Environmental Science of Ukraine
}

DOI: https://doi.org/10.31435/rsglobal_ijitss/30122019/6854

\section{ARTICLE INFO}

Received 15 October 2019

Accepted 18 December 2019

Published 30 December 2019

\section{KEYWORDS}

challenge, StartUp

EcoChallenge, information space, ecology, e-environment, social networks, startup,

innovation.

\begin{abstract}
The active development and start-up of startups is characterized by the positive dynamics of their growth. Increased activity to support startups in the field of government regulation, rapid development of educational space, the emergence of business incubators and startups, organizations that support the space, support for funding both external and internal.

The key aspects of the creation of environmental startups are considered, the mechanisms of their active promotion in the network are revealed. The role of the center of innovation activity of higher agricultural education institutions in the preparation of start-up projects has been determined through the prism of the main advantages and disadvantages of EcoChallenge.

From the standpoint of scientific and pedagogical paradigm, development of entrepreneurial and innovative activity, systematic approach to the formation of business competence. The semantic analysis of "Challenge" made it possible to determine the popularity of the word and the main stages of such an event as Challenge. The mechanisms of development of the eco-union are revealed.

The key aspects of the event information environment model for solving electronic communication issues and informing the participants are highlighted. Structural Elements of the Information Field Identified The color scheme and structure of the site were selected according to the purpose of the event.
\end{abstract}

Citation: Alona Nieliepova. (2019) Organization of Events «Challenge». Electronic Environment of Events. International Journal of Innovative Technologies in Social Science. 9(21). doi: 10.31435/rsglobal_ijitss/30122019/6854

Copyright: (C) 2019 Alona Nieliepova. This is an open-access article distributed under the terms of the Creative Commons Attribution License (CC BY). The use, distribution or reproduction in other forums is permitted, provided the original author(s) or licensor are credited and that the original publication in this journal is cited, in accordance with accepted academic practice. No use, distribution or reproduction is permitted which does not comply with these terms.

Вступ. За даними експертів - економіка України все більше спускається в стагнацію, окрім цього деякі політики вважають, що існує потенційна загроза дефолту. Напередодні Всесвітній банк порахував, що Україні знадобиться 50 років для досягнення сьогоднішнього економічного рівня Польщі та 100 років - рівня Німеччини. Одним 3 напрямів на вихід 3 кризового становища України, підтверджена закордонним досвідом розвиток соціального підприємництва, підтримка та реалізація стартап проектів - реалізація активної державної політики з впровадження стратегії розвитку інтелектуальної власності, підтримки стартап проектів. Країні потрібні творчі, ділові люди, сильні духом, що здатні приймати сміливі та нестандартні рішення, відповідальні та самостійні, а головне кваліфіковані фахівці, які здатні мислити креативно. Це підтверджується активною діяльністю Державної інноваційної фінансової-кредитної установи, метою якої є здійснення фінансової підтримки інноваційної діяльності суб'єктів господарювання різних форм власності.

Поряд 3 кризовими явищами в економіці, - стан навколишнього середовища та організація раціонального природокористування $\epsilon$ однією 3 актуальних проблем українських територій. Як говорять: «Біда лихо породила». Занедбані українські землі потребують дбайливого та мудрого користування енергетичними, земельними, водними та іншими 
ресурсами. Саме тому формування екологічної свідомості, нової системи цінностей $є$ визначальними напрямками діяльності в Україні.

В науковій літературі та мас медіа обговорюється ряд ключових питань, що пов'язані 3 інноваційними тенденціями - екологізацією систем життєдіяльності, а також екологізацію промислових підприємств та господарств. Науковці вважають екологізацію неупередженою процедурою, властивостями якої є спрямована діяльність на формування маловідходних та безвідходних технологічних процесів; заміна та відмова від забруднюючих екологію технологій; закриті виробничі цикли, використання альтернативної енергетики; розробка технологій та програм впровадження систем очищення газових викидів та стічних вод; комплексна переробки та сортування відходів, створення системи ринку органічної продукції.

У пошуках шляхів вирішення екологічних проблем та шляхів усунення кризових явищ постають в пріоритеті для України, тому вважаємо за необхідне підтримку в організації реалізації саме екологічних стартапів. Нині вже $є$ активні люди, що працюють в цьому напрямку, серед них Greencubator, Зелена школа та багато інших. На перший план виходить необхідність створити екоспілку людей, що об'єднують не тільки ідеї, а й дії, стає не першій сходинці до побудови суспільства, що $є$ орієнтованим на розвиток країни через особистісне зростання.

Засоби, що виступають об'єднанням думок людей різних верств населення конференції, зустрічі, круглі столи, обговорення. Проте проактивним вважаємо інформаційне поле, що буде виступати як сукупність зосередженої в даному обсязі простору-часу інформації щодо задіяних учасників серед існуючих стартап проектів та екологічного бізнесу.

Хоча значну роль у сучасному розвитку особистості відіграють конференції. Учасниками яких є не тільки здобувачі вищої освіти та науково-педагогічний склад, а й представники бізнесу, бізнес інкубаторів та стартап шкіл. Конференції, в яких приймають участь такі категорії людей спрямовані перш за все на обмін досвідом, думками, ідеями та веденням сучасних ділових бесід та переговорів. Проте для створення активної рушійної сили, необхідно взяти за основу більш дієвий захід, що включить не тільки представників науководержавних установ та бізнесу. Як найбільш очевидних для широкого кола людей, візьмемо за основу активні Челенджі. Механізми, що дозволяють об'єднати людей на основі використання соціальних мереж, дозволять охопити велику кількість людей і створити діючу екоспілку.

Формування бізнес компетентностей в даному випадку спрогнозуємо як мотиваційний поштовх для створення власного бізнесу. сформоване інформаційне поле користувачів дозволить розкрити потенціал стартап проектів що виходять на рівень розробки продуктів для широкого кола споживачів.

Для досягнення зазначеної вище мети необхідно вирішити наступні завдання:

1. Визначити семантичне поле значення Challenge, стартап та вплив заходу на створення екоспілки

2. Науково-педагогічний аналіз, в контексті формування стартап проектів, їх розвиток та реалізацію.

3. Визначити стартап проекти аграрного спрямування Миколаївської області, розвиток, аналіз їх діяльності.

4. Інформаційне середовище, в умовах проведеного заходу, - як складова електронного середовища формування бізнес компетентностей в університетах аграрного профілю.

Результати дослідження. Для вирішення поставлених завдань, по перше, звернемо нашу увагу на думку науковців лінгвістів, саме вони спостерігають за розвитком сучасних лексем та їх вплив на суспільства. Так однією з не відносно нових є лексема американського походження - challenge, що описують в мовному значенні як «виклик». Лексема «челендж»нині активний чином запозичується різними мовними системами, зазначають Т. Шкапенко, П. Шкапенко (2012). Науковці зазначають невідповідність тлумачення етнокультурними факторами, пояснюючи та наводячи приклади застосування цього слова в різних екскурсах (поетичному, політичному, економічному, соціальному та духовній сфері життя людини) (Шакін П., 2017).. Розуміємо що сутність слова відповідає деякому аспекту життя Америки та іï народу, дій, що стимулюють перемогу над труднощами, посилюючи наснагу до отримання успіху, благополуччя та щастя. Науковець проводить дослідження посилення леми слоганами, що пропонують діяти «You can do it», «We can do it», «Yes, we did it» (Шакін П., 2017). У французькому - challenge, звучить так само як і у англійській мові. Щодо значення - французи, 
вживають його завжди, коли хочуть підкреслити важливість якої-небудь події, щось цікаве i унікальне. Таким чином «Челендж» розуміємо як пропозицію вступити в боротьбу чи змагання.

Прихильність українців завоювали челенджі саме в соціальних мережах. Челенджі в інстаграмі, ютубі та інших популярних соціальних мережах приваблюють велику людей. У 2017 році до Міжнародного дня рідної мови Департамент суспільних комунікацій запустив флешмоб-челендж \#моямоваукраїнська. У 2018 році було запущено флешмоб «Колір настрою ЗЕЛЕНИЙ!», метою було призвати кожного підприємця та бухгалтера до раціонального використання паперу в роботі. Навіть президент України започаткував челендж щодо спортивного способу життя «Зе Кубіки». Деякі челенджи не тільки захоплюють, а й створюють настрій. Так, наприклад, Ice Bucket Challenge, за правилами якого учаснику необхідно облити себе відром крижаної води та перерахувати до добродійного фонду ALS Association 10 доларів, захопив декілька країн світу. Цей челендж залучив багато людей та сотні мільйонів доларів (The New York Times (2014, август 17)). В Україні цей челендж захопив відомих співаків Дзідзьо, Джамала, Дмитро Шуров, Світлана Лобода та багатьох політиків, серед яких мер Львову - А. Садовий, мер Києва - В. Клічко, М. Порошенко та інші.

Є практика і міністерських челенджів, так у Великій Британії було проведено City Challenge у 2008-2012 році, захід був направлений на поліпшення освітніх результатів для дітей 3 неблагополучних сімей.

$€$ челенджі-марафони «стрункості», або «відмова від цукру» на деякий проміжок часу; $\epsilon$ для саморозвитку, - читання книжок; змаганнях в комп'ютерних іграх; комічні, як наприклад випити 3 л молока, або нанести макіяж без дзеркала в прямому ефірі тощо.

Розуміючи проблеми навколишнього середовища, було запропоновано розробити захід «StartUp EcoChallenge», що об'єднає людей які ведуть екологічний бізнес, здобувачів вищої освіти, яких цікавить розвиток саме екологічних стратап проектів. У зв'язку з незаконною вирубкою дерев на території України (за даними Unian, скорочення лісів на Україні складає $11 \%$ (2017, липень 25)). Головним посилом челенджу було не тільки об'єднання людей, у яких в пріоритеті збереження природи та здоров'я людей, а й виконання конкретних дій озеленення територій в місті та поза його межами.

Повертаючись до теми стратап проектів зазначимо, що в Україні поступово формується інфраструктура підтримки стартапів. На сьогодні мережа бізнес інкубаторів та акселераторів за словами Н. Ситника (2017) налічує близько восьми десятків, переважно орієнтована на мале та середнє підприємництво. Проте, зазначає науковець, «Лише невелика кількість забезпечують комплексну підтримку стартапів на початкових етапах. робочий простір, менторство, консультації, інвестиції, зустрічі з потенційними інвесторами тощо» (2017, стор.118).

Концептуальні основи стартапів закладені в роботах С. Бланк та Б. Дорф $(2008,2012$, 2013), Benkler (2006), Е. Рica (2014). Стартап - це пошук бізнес моделі, інноваційної ідеї якої раніше не було, творча робота з нею. Стартап-середовище - це креативне середовище, в якому винахідники, навчаючись і спілкуючись, втілюють свої ідеї та розробки. D. Piscione досліджує характеристики першої і найбільш успішної стартової екосистеми світу, яка генерується більше 6000 інноваційних компаній. Вказує на характеристики екосистеми стартап проектів (2013).

Серед українських науковців, що вивчають стартап проекти - розвиток, проблеми та реалізацію - В. Геєць, І. Думанська, О. Курченко, О. Саліхова, Н. Ситник. На формування нових організацій інноваційного типу, звертає увагу В. Геєць. Виокремлюючи основним 3 головних питань фінансування науковець стверджує, що підтримка інноваційного розвитку необхідно здійснювати за рахунок залучення інвестицій від підприємців та ресурсів венчурного характеру (2015). I. Думанська звертає увагу на аспекти фінансування стартап проектів в агропродовольчому виробництві (2018). О. Саліхова, проводить глибинний аналіз міжнародного досвіду. Визначаючи методології та підходи роботи зі стартапами у країнах: США, Сполучене Королівство, Німеччина, Італія, Канада, Китай, встановлює зв'язки обгрунтовуючи стратегії побудови національних високотехнологічних виробництв та варіанти їхньої реалізації (2012). О. Курченко визначає поліаспектну статистичну форму для опитування стартапів в Україні для оцінки їхніх ресурсів та результатів, перешкод на шляху інноваційної діяльності та інтеграції у європейський науково-технологічний простір (2016). Н. Ситник описує основні характеристики системи життєзабезпечення екосистеми стартапів, серед яких: юридично-правові засади; інвестування (приватний і державний капітал, бізнес-янголи, 
венчурний капітал, інвестиційні компанії та фонди, краудфандингові платформи); підготовка та навчання (стартап-школи, навчальні курси, інкубатори, створення вільного робочого простору, менторство, майстер-класи); організація заходів щодо презентації стартап проектів (зустрічі $з$ міжнародними експертами та інвесторами, організація виставок стартапів, конференцій, хакатонів (hackathon), челенджів (challenge), битв (battle), марафонів (marathon) (2017).

Розглянуті нами наукові джерела дають підстави для наступного висновку: формування бізнес свідомості можливе через проведення ряду заходів та розбудови необхідної інфраструктури для розвитку підприємницької діяльності та інновацій у вигляді стартап проектів; Визначено основні проблеми, що стають перепонами у розвитку інновацій - серед них фінансування та юридично-правові. Відстоюючи позиції розвитку науковці втілюють в життя європейський та американський досвіди роботи з ідеями та підтримкою їх на ринку.

Для визначення проблем, що стримують бажання втілити власні ідеї, проведено анкетування здобувачів вищої освіти (608). Дані опитування свідчать про те, що здобувачі вищої освіти розуміють важливість бізнесу та підприємництва для розвитку країни у переважній більшості випадків анкетовані наводили обгрунтовані відповіді з приводу необхідності розвитку підприємництва для національної економіки. Один на 32 опитуваних вже мав офіційні документи, що підтверджуюють його право здійснювати підприємницьку діяльність, загалом ця кількість склала 19 здобувачів вищої освіти. Тривожить той факт, що значна частина здобувачів $(80,1 \%)$ взагалі не змогла ідентифікувати різницю між бізнесом та підприємництвом. Також значна кількість респондентів не знає основні моделі ведення підприємницької діяльності $(89,4 \%)$. Більше половини $(70,2 \%)$ не вміють розподілити фінанси та скласти список проектів, справ, покупок, самоосвіти і розваг. Цікавим виявився той факт, що мають ідею для бізнесу майже половина анкетованих здобувачів вищої освіти (45,9\%).

Як бачимо, здобувачі вищої освіти розгублено відповідають на питання, хоча розуміють важливість розвитку підприємницької справи. Але знання щодо елементарних аспектів ведення бізнесу - планування та знання бізнес моделей повинні бути в пріорітетах вивчаємої дисциплни «Основи економічної теорії».

Співставивши відповіді на запитання можна дійти висновку, що більшість здобувачів бажає відкрити власну справу, розуміє важливість розвитку малого та середнього бізнесу, проте не має знань з основ економічної теорії, що свідчить про слабку обізнаність майбутніх аграріїв. Відбір здобувачів вищої освіти на конференцію «StartUp EcoChallenge» засновано на відповідях у анкеті, акцент було поставлено на знання з економіки та ведення підприємницької діяльності. У загальній кількості ця цифра становила 176 осіб.

Взявши за основну мету ознайомлення з різними види бізнесу та варіанти обраних моделей було прийнято рішення провести захід, що буде слугувати поштовхом для розвитку власної справи. Захід було спрямовано на активне спілкування та інтелектуальну взаємодію між представниками бізнесу і молоді, окрім цього було залучено організації, що сприяють розвитку бізнес компетентностей.

Заздалегідь перед проведенням заходу з учасниками було обговорено моделі ведення ділової бесіди та специфіку мовного етикету, стратегії та тактики спілкування. Звернули увагу на відповідні розділи 3 «Ділової української мови», що вивчалась всіма здобувачами на першому курсі.

Вибір екологічного направлення обгрунтовувався екологічними проблемами в Україні. Екологізація, як нова течія, що спонукає проникнення у сферу всіх систем життєдіяльності людини, здатність кожної особистості зберегти екосистему планети. Відомий громадський діяч, який $\epsilon$ автором більше 50-ти книг на екологічну, природоохоронну, зоозахисну, екофілософську та історичну тематику, Володимир Борейко звертає увагу в своїх роботах на екологічні проблеми України. Серед них діяч називає: забруднення водних ресурсів; скорочення середньої тривалості життя жителів України; забруднення повітря; скорочення тваринного і рослинного світу; проблема сміття і побутових відходів; проблема незаконної забудови берегів річок, озер і морів; наслідки чорнобильської катастрофи.

Метою виступів представників екологічного бізнесу була внутрішня потреба поділитися досвідом в професійному співтоваристві, залучити молодь до співпраці та здійснити виклик молоді і перевірити готовність до активних та рішучих дій. Розкриття кейсів власних бізнес моделей представників екологічного бізнесу були спрямовані на формування лояльності слухачів 
до екологічного виробництва та обмін досвідом з кращими фахівцями в сфері екологічного виробництва міст Миколаєва, Одеси, Херсону. Відповідно до зазначеного, було організовано і структуру доповідей: історія та місія створення бізнесу; мета та задачі, що переслідує засновник в бізнесі; розкриття бізнес моделі, що було обрано для досягнення поставленої мети; якісні та кількісні показники, що досягнуті підприємством на сьогодні; перспективи розвитку; отримання зворотнього зв'язку від слухачів.

Розглядаючи електронне середовище для формування бізнес компетентностей як складну структуру, розкриємо інформаційний простір «StartUp EcoChallenge», що є однією складовою (рис. 1.). Інформаційний простір виконував наступні задачі: 1. Інформаційна підтримка учасників; 2. Популяризація та розвиток екологічного бізнесу; 3. Створення екоспілки діючих людей. 4. Інформаційна взаємодія забезпечує обмін інформацією між учасниками, а також моніторинг процесу обміну інформацією. Опис сервісів наведено нижче.

Концепція сайту як інформаційного простору, доступного різним категоріям користувачів , до його структури входить:

Header: інформація щодо заходу: місце, час, назва, лозунг, рядок меню

Основна сторінка:

1. Логотип, назва, кнопка реєстрації.

2. Інформація щодо проблеми заходи, щляхи ії вирішення.

3. Категорії проектів.

4. інформація щодо створення екоспілки, кнопка приєднатись.

5. Інформація щодо спікерів: ПІБ, посада, посилання на соціальні мережі та сайт підприємства, тема доповіді, місія компанії.

6. Програма.

7. Карта.

8. Реєстрація.

9. Спонсори.

Footer: інформація про організаторів, час, назва, хештег під яким можна знайти в соціальних мережах, соціальні мережі, логотип, лозунг.

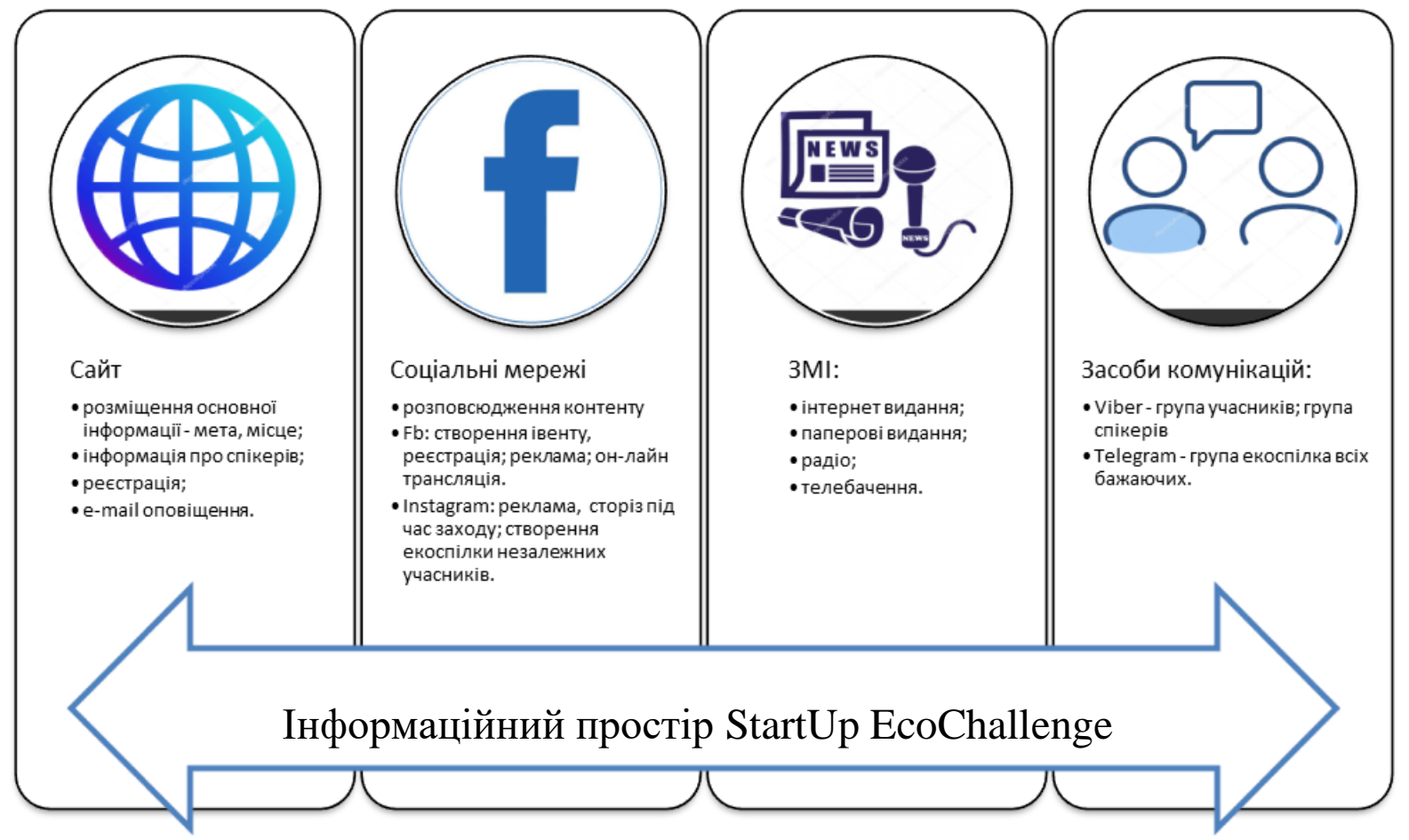

Puc. 1. Інформаційний простір StartUp EcoChallenge

Вибір кольорових палітр щодо візуалізації даних на сайті було здійснено за допомогою онлайн сервісу colorscheme (Рис 2.), відповідно до основних кольорів на логотипі, що символізують підключення до екоспілки. Основними кольорами виступили зелені відтінки, як уособлення розбудови життя людини у рівновазі 3 природою. Окрім цього зелений колір уособлюють як 
свободу дій, мудрість, гармонію, стабільність, рівновагу, рівність і впевненість. Акценти, обрано 3 додаткових та вторинних кольорів.

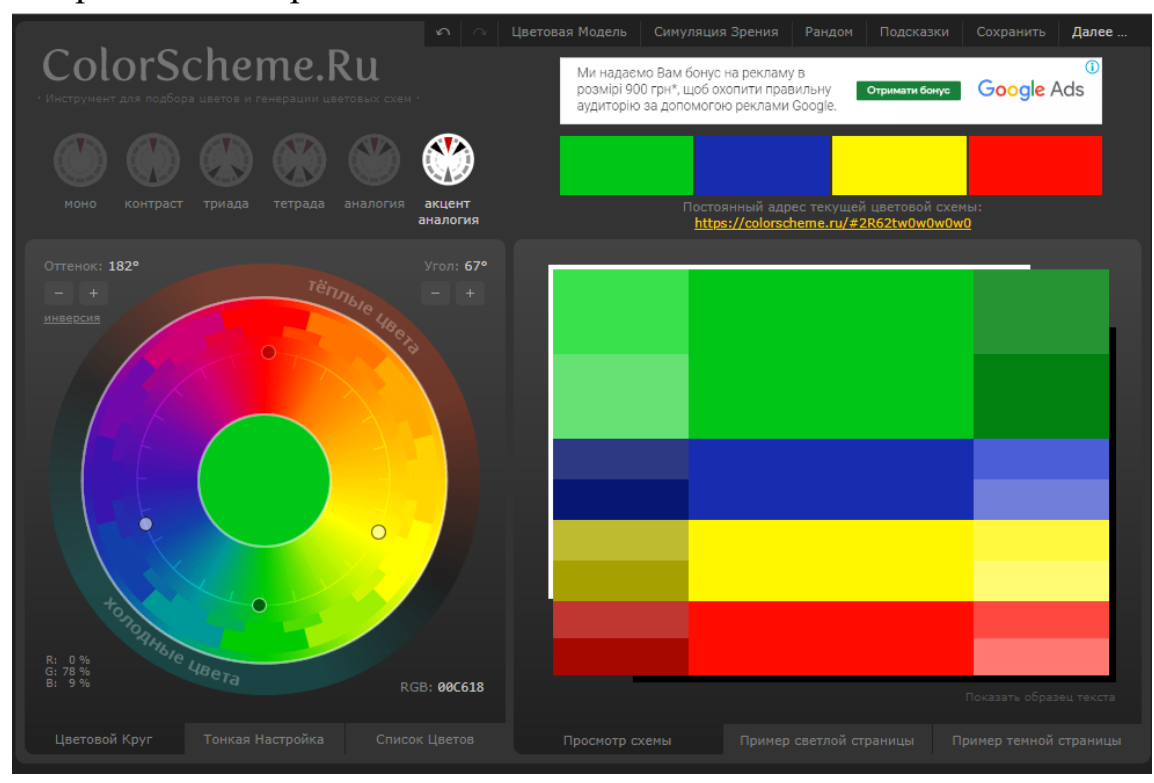

Рис 2. Онлайн сервіс colorscheте для вибору кольорової гами сайту

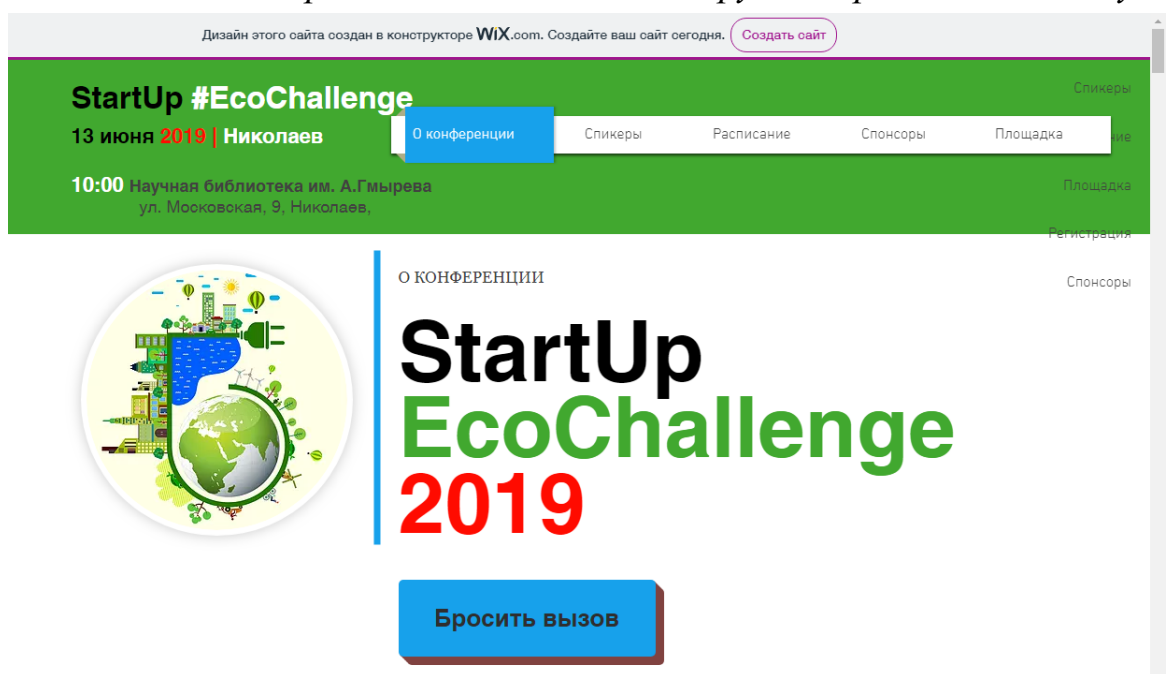

Pис. 3. Стартова сторінка заходу «StartUp EcoChallenge», платформа WIX (1 версія)

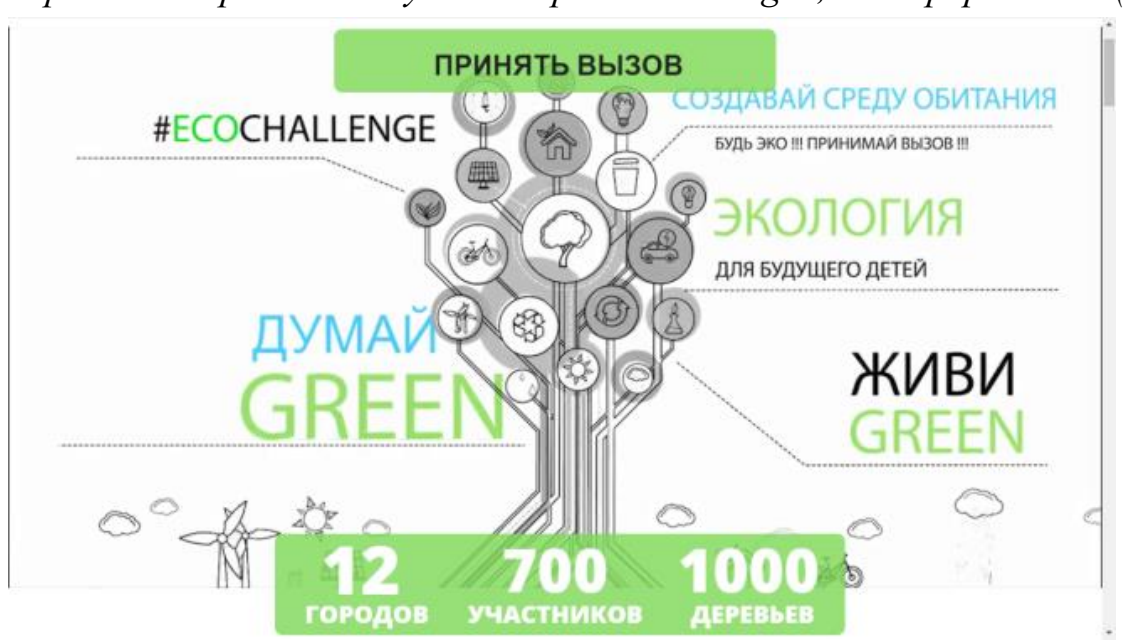

Puc.4. Стартова сторінка StartUp EcoChallenge розроблена на Wordress

Одним із варіантів вирішення проблеми екології та шляхів усунення кризових явищ вважаємо за необхідне підтримку в реалізації саме екологічних стартапів. Інформаційне поле, 
що буде виступати як сукупність зосередженої в даному обсязі простору-часу інформації щодо задіяних учасників, існуючих стартап проектів, екологічного бізнесу.

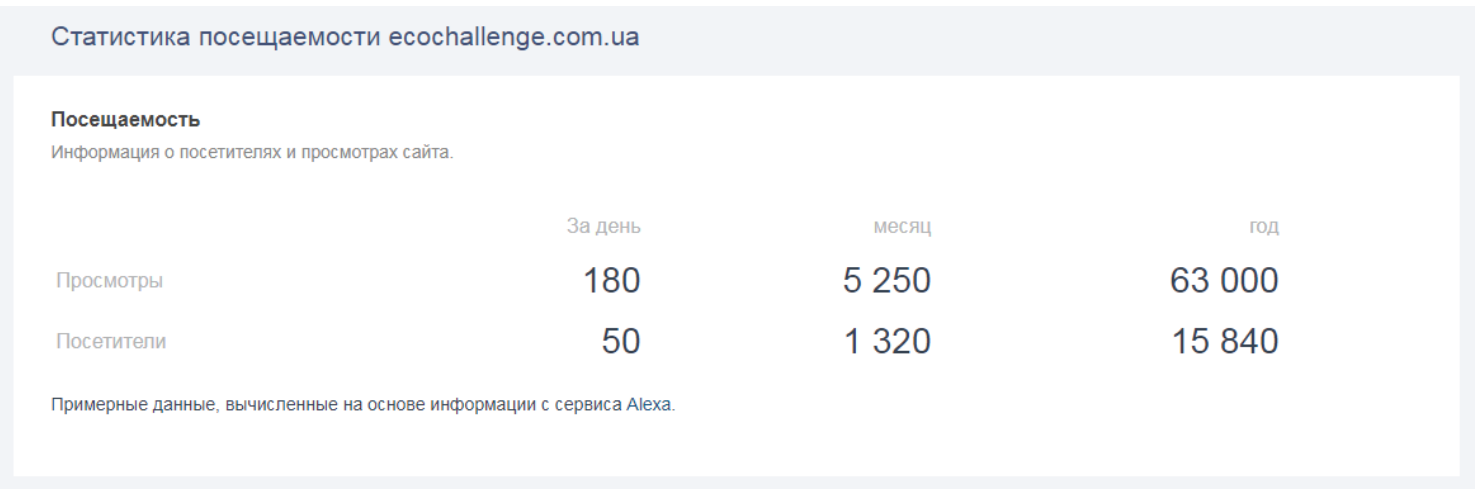

Рис. 5. Ведені показники заходження на сайт на момент 19.11.2019

Інформаційний потік на сайті http://ecochallenge.com.ua/

На думку А. Соколова, електронна комунікація - це новітній вид смислової соціальної комунікації, яка охоплює широке коло техногенних комунікаційних каналів, заснованих на дротовому та радіозв'язку, магнітному та оптичному записі інформації. Інформаційний потік, що в загальному випадку сукупність інформації, що переміщається в інформаційному просторі по каналу комунікації. У даному випадку являє собою Інформаційні потоки в соціальних мережх, що дозволяють режимі он-лайн розповсюджувати інформацію тим самим створюючи інформаційний потік, поділяючи на окремі інфосфери кожного учасника та його підписників. Взаємодію між ними, через ріні канали комунікації direct, Story, IGTV, он-лайн трансляція (Instagram), Messenger, Сторіз, он-лайн трансляція FB, i так далі залежно від наявності каналів комунікації у учасника EcoChallenge.

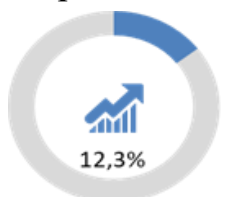

Науковці

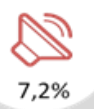

3MI

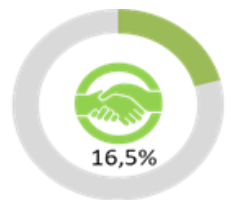

Представники бізнесу

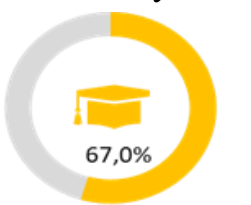

Здобувачі вищої освіти

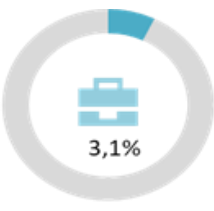

Держслужбовці

Pис. 5. Зведені показники присутності різних груп учасників заходу «StartUp EcoChallenge» м. Миколаїв

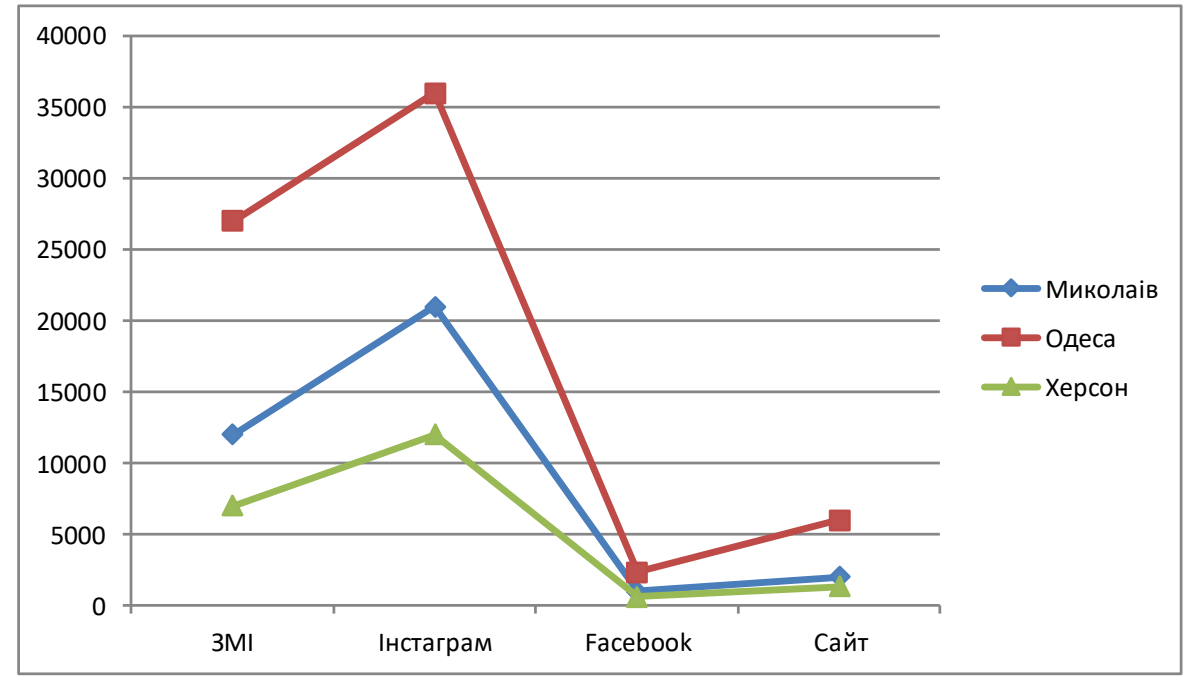

Рис. 6. Інформачійне поле створене 3МI, соиіальними мережами та сайтом.

Висновки. Результати семантичного аналізу та процесів розповсюдження заходу в межах країни та світу ефективно демонструють динаміку зміни настрою та використання елементів англомовної лексеми challenge, що визначаємо як змагання та виклик до дій. Аналіз 
науково-методичної літератури стартап проектів дав можливість визначити етапи розвитку, проблеми та реалізацію бізнес ідей. Визначення екологічного направлення, обгрунтовано проблемами екології на території України.

В організаційно-технічному аспекті структуру інформаційного простору становить сукупність блогів, соціальних медіа, веб сайту, підготовленого заздалегідь контенту, реклама їх супроводу, використання, інформаційно-телекомунікаційних систем, мереж, додатків та організаційних структур, що функціонують на основі певних принципів і за встановленими правилами, що забезпечує інформаційну взаємодію користувачів, а також задоволення їх інформаційних потреб.

Результати конференції сприяли розвитку екологічних стартапів, створення інформаційного поля засобами розповсюдження через мережу Інтернет та соціальні мережі присутності на заході «StartUp EcoChallenge». Взяття участі у конференції дає можливість розвитку екологічних ідей та підвищення обізнаності, отримання практичного досвіду здобувачами вищої освіти про моделі бізнесу, впровадження бізнес ідей у життя засобами навчання у стартап школі, отримання м'яких навичок у бізнес інкубаторі, вивчення цільової аудиторії, визначення механізмів поширення продукту на краудфандинговій платформі. Окрім цього захід мав мотиваційне спрямування, отримання натхнення для почуття спільності, поглибленого зв'язку з природою і бажання вирощувати зелені насадження, створювати позитивні глобальні зміни в напрямку стійкості.

\section{ЛІТЕРАТУРА}

1. Benkler, Yochai. (2006). The Wealth of Networks: How Social Production Transforms Markets and Freedom. Yale University Press.

2. Blank, Steve Gary, and Bob Dorf. (2012). The Startup Owner's Manual: The Step-by-Step Guide for Building a Great Company. K\&S Ranch, Incorporated.

3. Blank, Tali Hadasa. (2008). "The Effects of Founding Team Composition on the Success of Israeli New Ventures in the High-Technology Sector". Bar Ilan University, Israel.

4. Ice Bucket Challenge' Has Raised Millions for ALS Association, The New York Times (27 July 2016). Retrieved from https://www.nytimes.com/2016/07/28/health/the-ice-bucket-challenge-helped-scientists-discover-a-new-gene-tied-to-als.html.

5. Piscione, Deborah Perry. (2013). Secrets of Silicon Valley: What Everyone Else Can Learn from the Innovation Capital of the World. Macmillan.

6. Research and analysis. Evaluation of the city challenge programme. https://www.gov.uk/government/publications/e valuation-of-the-city-challenge-programme. From: Department for Education. Published 28 June 2012

7. Shkapenko T., Shkapenko P. (2012). Import of American Concept „Challenge“// Auspicia. Praha. , № 1. C. 85-90.

8. Бланк С. (2013). Стартап: настольная книга основателя / С. Бланк, Б. Дорф. - М.: Альпина Паблишер, 616 с.

9. Вырубка леса в Украине достигает масштабов экологического бедствия. (июль 25, 2017). Unian. Retrieved from: https://www.unian.net/ecology/naturalresources/2048064-vyirubka-lesa-v-ukrainedostigaet-masshtabov-ekologicheskogo-bedstviya-video.html

10. Геєць В.М. (2015). Бар'єри на шляху розвитку промисловості на інноваційній основі та можливості ї подолання. Економіка України. № 1. С. 14.

11. United Nations Ukraine (Вересень 15, 2017). Цілі сталого розвитку 2016-2030 Національна доповідь 2017 Retrieved from: http://www.un.org.ua/ua/tsili-rozvytku-tysiacholittia/tsili-staloho-rozvytku

12. Думанська I.Ю (2018). Стартап як платформа для фінансування інноваційного процесу в апк. Приазовський економічний вісник. Гроші, фінанси і кредит Випуск 2(07). - с. 122-128

13. Рис Э. (2014). Бизнес с нуля. Метод Lean Startup для быстрого тестирования идей и выбора бизнесмодели $=$ The Lean Startup: How Today's Entrepreneurs Use Continuous Innovation to Create Radically Successful Businesses. - М.: Альпина Паблишер,-256 c.

14. Остапчук Ю. (2016). Роль електронної комунікації в інформаційному суспільстві. Вісник Книжкової палати. № 5 39, с. 38-40

15. Саліхова О. Б. (2012). Високотехнологічні виробництва: від методології оцінки до піднесення в Україні: монографія. Київ,. 624 с.

16. Саліхова О.Б., Курченко О.О. (2016). Створення статистичного підгрунтя для оцінки особливостей інноваційних стартапів України. Статистика України. № 1. С. 18-21.

17. Ситник H.I. (2017). Сучасний стан та перспективи розвитку екосистеми стартапів України / Н. I. Ситник // Науковий вісник Херсонського державного університету. Сер. : Економічні науки. — Вип. 27(2). - C. 117-120. - Режим доступу: http://nbuv.gov.ua/UJRN/

18. Скаршевский В. (Февраль 23, 2019). «Украина топчется в экономическом болоте». https://golos.ua/i/666750

19. Шакин П. В. (2017) Сдвиги лексической сочетаемости лексемы вызов (на материале текстов СМИ) В лаборатории ученого, с. 181-189. Електронний pecypc: http://elar.urfu.ru/ Доступ до ресурсу: http://elar.urfu.ru/bitstream/10995/54434/1/iurp-2017-168-21.pdf Дата звернення: 20.06.19

20. Шкапенко Т. (2016). Англо-американский концепт "challenge" в славянских языках // International scientific review. №4 (14). Доступ до ресурсу: https://cyberleninka.ru/article/n/anglo-amerikanskiykontsept-challenge-v-slavyanskih-yazykah (дата звернення: 21.06.2019). 